\title{
MGNREGA Vis-à-Vis Tribal Livelihoods: A Study in Kurung Kumey District of Arunachal Pradesh
}

Tame Ramya $^{\dagger}$

\section{Abstract}

Mahatma Gandhi National Rural Employment Guarantee Act (MGNREGA) is considered as a "Panacea" for eradicating rural poverty and unemployment. Its objectives are: (a) provide, on demand, not less than one hundred days of unskilled manual work in a financial year to every household in rural areas; (b) create productive assets of prescribed quality and durability through wage employment; (b) strengthen the livelihood resource base of the rural poor; (c) proactively ensure social inclusion; and (d) strengthen Panchayat Raj Institutions.

Arunachal Pradesh, one of the eight north-eastern states of India is a rural-based state where the majority of the population depends on agriculture. In this context, the rural employment guarantee programme has played a significant role in alleviating rural poverty by giving them 100 days guaranteed job in a year. In the state, National Rural Employment Guarantee Act (NREGA) during 2006 was initially launched only in one district and was further extended to two more districts the next financial year in 2007. Currently, the programme is being implemented in all the 16 districts of the state barring few recently created districts. While some districts in Arunachal Pradesh are performing very well; some others are worst performers, and Kurung Kumey is one of the worst performing districts of the state regarding implementing this programme.

Thus, the present study attempts to critically examine the implementation process of this programme and its impact on tribal livelihoods that is, to what extent MGNREGA has given justice in sustaining the livelihoods of poor tribal communities in a Panchayat of Kurung Kumey district, Arunachal Pradesh. The study reveals that there is little impact of MGNREGA on tribal livelihoods. The faulty implementation strategy has ruined the spirit of this programme. Religion and street biases and favouritism in case of distribution of job cards, the dominance of dominant families, poor leadership and improper coordination among the stakeholders have stood as significant hurdles in this programme.

Keywords: MGNREGA, Poverty, Tribal Livelihood, Kurung Kumey, Arunachal Pradesh, India

\footnotetext{
${ }^{\dagger}$ Assistant Professor, Department of Anthropology, Faculty of Social Sciences, Dera Natung Government College, Itanagar, Papum Pare District - 791 113, Arunachal Pradesh, India, Email: taramya@live.com

(C) 2018 Ramya. This is an Open Access article distributed under the terms of the Creative Commons Attribution License (http://creativecommons.org/licenses/by/2.0), which permits unrestricted use, distribution, and reproduction in any medium, provided the original work is properly cited.
} 


\section{Introduction}

The development of rural India is crucial for inclusive and impartial growth and for releasing the enormous potential of the population that is presently trapped in poverty and its associated deprivations (Rengasamy and Kumar, 2011: 36). Mahatma Gandhi National Rural Employment Guarantee Act (MGNREGA) is a part of the Government of India's broader commitment to inclusive growth, which aims to address both the economic and social underpinnings of poverty (Holmes, Sadana and Rath, 2011). This flagship scheme aims to guarantee the 'right to work' and ensure livelihood security in rural areas by providing at least 100 days of guaranteed wage employment in a financial year to every household whose adult members volunteer to do unskilled manual work (Borah and Bordoloi, 2014: 40). The MGNREGA workers' rights comprise of employment on demand, minimum wages, gender parity of wages, and payment of wages within 15 days, as well as the provision of basic worksite facilities, among others (Das, 2012: 210). The scheme has also made some special provision for Scheduled Castes and Scheduled Tribes category. Projects providing irrigation facility to land owned by Scheduled Castes and Scheduled Tribes comes under permissible work and people from the Scheduled Castes and Scheduled Tribes, who works in their own fields, are eligible to get wages under this scheme (Gupta, 2014: 234). It is the first programme in the country to provide guaranteed livelihood security to rural poor with an initial outlay of ₹113000 million in the year 2006-07. The purpose of this article is to assess MGNREGA versus tribal livelihoods in the Kurung Kumey district of Arunachal Pradesh. The article begins with a rationale of the study. Following this, a background of this programme is outlined alongside a review of relevant literature. The findings and discussions are covered in the final sections.

\section{The Rationale of the Study}

This study attempts to understand the implementation procedures of MGNREGA and its impact on tribal livelihoods in a tribal dominated village of Kurung Kumey district, Arunachal Pradesh. This state is one of the eight north-eastern states of India, which is a rural-based state and the majority of the population depend on agriculture. This study focuses on the role of the Gram Panchayat (GP) in generating sufficient employment opportunities through MGNREGA. In doing so, it probes at the procedures for registration, issuance of job cards, and application for employment. This would enable us to understand and examine the institutional mechanisms under which the entire programme is being implemented. The problems and prospects of MGNREGA can then be better understood, and accordingly, necessary measures can be devised to make the programme realise its set objectives. The outcome of the study will help in understanding the problem of implementation of the scheme. It will facilitate in devising better policy and strategy for the future.

Some researchers conducting a study on MGNREGA are confined mostly to economic aspect and are not comprehensive (Sissal \& Sharma, 2014; Koyu, Sarkar, Singh, \& Singh, 2017); very few of them have emphasised on the implementation aspects of MGNREGA. However, these researchers have also failed to cover the social aspects of the scheme. This study, therefore, takes on its task of discussing both implementation and the impact of MGNREGA in the tribal village of Kurung Kumey district of Arunachal Pradesh. The following questions are investigated in this study:

- To what extent MGNREGA has helped in sustaining the tribal livelihoods?

- Does MGNREGA have been successful in improving the living conditions of the tribal poor?

- Does it promise a job to the needy?

- Has it been successful in reducing migration from the rural areas?

- Is it a livelihood generating programme or simply a wage-earning scheme?

- Are the people aware of the MGNREGA work? 
- Is the Act properly implemented as per its framed norms?

\section{MGNREGA: An Overview}

Since Independence, the Government of India has launched a number of Central Schemes/ Centrally Sponsored Schemes (CSS) and Community Area Development Programmes (CADP) in the areas of health \& family welfare, education, employment \& poverty eradication, agriculture, women \& child development, sanitation, housing, safe drinking water, irrigation, transport, tribal development, border area development, social welfare, etc. both in rural and urban areas of the country, including Arunachal Pradesh. The main objectives of all these schemes are to generate employment, improve the quality of life, and remove poverty \& economic inequality and human deprivation. Besides, these schemes are also aimed at the creation of basic infrastructure and assets essential for economic development in rural areas.

MGNREGA has been implemented after almost 56 years of experience of other rural employment programmes, which include both CSS and those launched by the respective State Governments. When MGNREGA first introduced in 200 most backward districts of the country in February 2006, it was proposed to extend to the remaining districts only after five years, depending on the popularity and success of the Act (Didde and Muthaiyan, 2013: 57). However, in the next year itself, the Act was extended further to 130 more districts. And after that within a year the Act was implemented in the whole country with the exception of districts that have a hundred per cent urban population. On 2nd October 2009, it was renamed after Mahatma Gandhi, the Father of the Nation aimed at making the Act more reachable to the masses, and thus it became Mahatma Gandhi National Rural Employment Guarantee Act (MGNREGA).

In the context of Arunachal Pradesh, this Act was initially launched only in one district and was further extended to two more districts the next financial year in 2007. Currently, the programme is being implemented in all the 16 districts of the state barring few recently created districts. While some districts in Arunachal Pradesh are performing very well; some others are the worst performers, and Kurung Kumey is one of the worst performing districts of the state regarding the implementation of this programme.

\section{Review of Literature}

There is a large literature on the impact of MGNREGA on rural livelihood. For instance, Mishra, Behera, and Nayak (2010) examine the impacts of MGNREGA as a development delivery institution for the tribal communities versus other social groups across different states of the country using the framework of new institutional economics. Their study found a number of state-specific, socio-economic institutional factors such as family income, health status, education, etc. responsible for the variations in the impacts of this scheme. They, therefore, suggests institutional reforms and convergence of the development initiatives of the Ministry of Tribal Affairs with the MGNREGA in order to realise the optimal potential of the scheme, and, in particular, to ensure greater livelihood opportunities for the marginalised groups and their entitlement to productive resources with greater socioeconomic and political empowerment. Similarly, Menon and Dixit (2013) noted that the scheme is a vital livelihood option for poor households without productive land or marketable skills because it ensures nondiscriminatory access to work and the timely payment of fair wages. Their study notes a positive impact of this transfer on household income, monthly per capita expenditure, food security and health of the beneficiaries. Overall, while there are several indications of the significant impact of the scheme such as raise in family income, improvement in health status, creation of more assets, etc., it has even more significant potential in terms of poverty alleviation. Indeed, according to the scholars, this scheme has contributed to ensuring a higher intake of food and food availability (Menon and Dixit, 2013). 
However, using the evidence from the report of the Comptroller and Auditor General of India and other studies, Bhattacharjee (2017) critically presumes that the delivery and outcome of such schemes would always remain suboptimal, and instead of reducing poverty, they would only perpetuate it while draining precious resources despite loud protestations of its supporters. He also noted that the MGNREGA has not been able to make much of a dent in rural poverty. To this end, he suggests some innovative ways to help improve the outcome of the scheme such as by addressing poverty by building capacity, protecting the environment, improving health and sanitation, by providing drinking water, building networks for irrigation, roads and creating other assets in the rural areas (Bhattacharjee, 2017: 32).

In another study, Chatterjee (2017) carried out a review of the several schemes like MGNREGA, Deendayal Antyodaya Yojana-National Livelihoods Mission (DAY-NRLM), Pradhan Mantri Awaas Yojna-Grameen (PMAYG), and Pradhan Mantri Gram Sadak Yojana (PMGSY) across eight states-Andhra Pradesh, Madhya Pradesh, Jharkhand, Karnataka, Maharashtra, Odisha, Rajasthan, and Tripura. From each of these states, he selected two diverse districts based on the criteria of agriculturally backward, high level of poverty, tribal dominated areas vis-à-vis industrially advanced or located in coastal areas. His findings suggested more of such study to be carried out in rest of the states in order to assess the impacts and benefits of these schemes in the country.

In a slightly different context, Bit and Banerjee (2013) attempts to verify whether the current forest management policies of India have ensured biodiversity conservation and in turn, livelihood protection for the forest-dependent people through a household survey conducted in the Birbhum district of West Bengal. Their findings demonstrated a cultural transition among the local people who used to be selfsustained forest-dependent livelihood; however, due to forest degradation and nonavailability of necessary resources or services, they were gradually exposed to the outer world and enhanced participation in general economic development related activities. An important implication of their study is the presence of cultural migration, which is pulling the forest dwelling tribal people out of their natural habitat and community living and forcing them to be a part of the outside monetised economy governed by the market incentives. According to their study, the tribals now take money as the only compensation to do any work instead of once practised barter system. Getting formal education from mainstream institutions, they have started socialising outside their own communities and mould themselves for a better career in the outside world. Similar observations were found in the study area where the rate of dependence on natural resources are declining and their dependence on Government schemes like MGNREGA are increasing.

Drawing on a mixed methods approach, Holmes, Sadana, and Rath (2010; 2011) conducted a research in four research sites (villages) in two districts in Madhya Pradesh (Khargone and Betul) to assess the extent to which MGNREGA incorporates an understanding of gender inequality to support the inclusion of women, especially those from marginalised communities, in India's poverty reduction and growth processes. Their findings demonstrated that the higher wages women receive from MGNREGA represent a significant improvement in terms of women's earning opportunities and increased contribution to the household income. However, even though the act stipulates that households be entitled to 100 days of employment and equal wages, a closer look at the number of days of work and the actual provision of wages suggest a somewhat more different picture of the gender dimensions of MGNREGA. Their analysis of MGNREGA through a gender lens highlights specific progressive gender-sensitive design features, which support women's participation in employment - through the one-third reservation, the provision of equal wages for women and men through the Equal Remuneration Act, and the promotion of women's active engagement in the planning 
and evaluation of community assets through, for example, the social audit forums. However, their findings further demonstrate that both the conceptual design of MGNREGA and its implementation need to be strengthened to support gender-equitable outcomes including the provision of quality childcare facilities at the sites of MGNREGA activities.

Against these backdrops, this article aims to assess the impact of MGNREGA on the tribal livelihoods in the Kurung Kumey district of Arunachal Pradesh. The objectives central to this study are: to understand the implementation procedure of MGNREGA in the village; and to understand the impact of MGNREGA on tribal livelihoods.

For accomplishing the objectives, the Hiya village located in the Nyapin sub-division of Kurung Kumey district was chosen. This village is located about 18 kilometres away from Nyapin Town, the sub-division headquarters. Hiya, the largest village (in terms of area and population) of Kurung Kumey district is located in the extreme eastern part of the Nyapin subdivision, one of the oldest administrative centres of the state, with whom a status of small town was declared in the same name in 1953 (Ramya, 2014). The village has a population of more than 1,000 people spreading over 308 households as per the revised electoral rolls of 2011. This, however, excludes the population below 18 years of age.

The Hiya village is the blend of two villagesHiya-I and Hiya-II and one adjoining sub-village, that is, Lumtey. Hiya, once a single village was bifurcated into two villages in the year 2001 where the adjoining sub-village Lumtey was shifted under Hiya-I. The administrations of the village are run under Panchayati Raj Institutions (PRIs) with two Anchal Samiti Members (ASMs) and eight Gram Panchayat Members (GPMs). Besides, the village has two Head Gaon Burahs (HGBs) leading few other Gaon Burahs (GBs). The mosaic of these two combinations looks after the administrations of the village. The methodological issues are discussed in the next section.

\section{Research Methodology}

For the selection of the beneficiary respondents, two stages were followed. In the first stage, purposive sampling method was adopted. In the second stage, for selecting the sample respondents, random sampling method was adopted. A sample of 80 households including both job cardholders and non-job cardholders were selected. Here, non-job cardholder households were selected to explore the reasons for their non-participation in the activities of this scheme. Out of 80 households, 15 households fail to have jobcards.

Data were collected from both primary and secondary sources. Primary data was collected from all the stakeholders of MGNREGA. Questionnaire surveys with the different stakeholders engaged in MGNREGA in the study site were organised. Semi-structured informal interviews were also conducted from selected households. Transect walk into the MGNREGA worksites were conducted to have the first-hand experience on the MGNREGA sites of the village. In order to gather quantitative data, a household survey was conducted using schedules. The secondary data was collected from official records, policy documents, published reports, journals, and other related literature. The results and discussion are presented in the following sections.

\section{Findings and Analysis}

As stated above, starting from 200 districts, the coverage of MGNREGA was increased to all the rural districts across the country. However, despite coming out of a nationwide struggle for the enactment of Employment Guarantee Act (EGA), the performance of the MGNREGA varies across the states. Hence, one of the key questions that arise here was on the appropriate implementation of the Act, which can give justice to the poor for whom the Act was intended. To a certain extent, the effective implementation is consequent upon greater awareness and participation of the beneficiaries; and for this Panchayati Raj 
Institutions (PRIs) have a more significant role to play according to the Act.

It is reiterated that study is confined to a tribal village under Nyapin block in Kurung Kumey district of Arunachal Pradesh. The sample used in the current study consists of 80 households out of registered 273 households including 65 (81.25\%) job cardholders and 15 (18.75\%) nonjob cardholders. An analysis of the primary data collected from these households presents the following results:

\section{Caste of the Respondents}

The sample households selected for the study covered only those households that belong to scheduled tribe population.

\section{The Religion of the Respondents}

The religion of households plays a vital role in rural development. The ideological differences based on various religions influence the implementation process of any project.

The Figure 1 shows that among the sample respondents, 76 of the households (95\%) belong to Christian. Only four households (5\%) are indigenous believers.

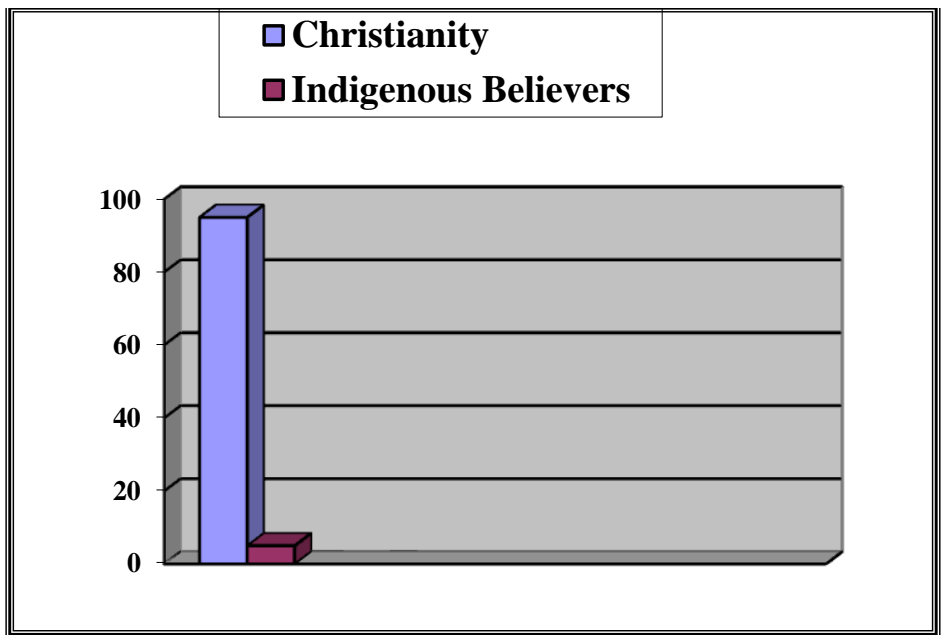

Figure 1: Religion of the Respondents

Source: Survey Data

\section{Main Source of Livelihood}

Almost all the households were depending on natural resources like land, water and forest for their livelihoods. However, in the course of time, a lot of transformation has taken place. The intervention of various development projects has brought a lost to the natural resources alongside disturbing the symbiotic relationship between human and nature. This finding is similar to the arguments made by Bit and Banerjee (2013).

\section{Distribution of Job Cardholders According to Caste, Religion, Educational Qualification, and BPL Cardholders}

The implementation of MGNREGA came with the introduction of job card to the villagers. The
Table 1 shows that all the sample job cardholders (100\%) belong to ST category. Out of the entire sample job cardholders, 62 (95.4\%) are Christian, 34 (52.3\%) are illiterate, and $18(27.7 \%)$ are non-BPL cardholders.

Among the sample of non-job cardholders (15), the majority (9) of whom are STs (60\%), while $11(73.3 \%)$ are illiterate. Thus, there is a need for improvement, as many of the respondents in this village have not obtained a job-card as yet. Among the non-job cardholders, many families belong to the most vulnerable sections like women-headed households, senior citizens, and poorer sections while the rich, influential people, authorising committee itself are receiving many benefits on the name of the poor and unemployed youths. 


Table 1: Distribution of Job Cardholders According to Caste, Religion, Educational Qualification
and BPL Cardholders

Source: Survey Data

\section{Implementation of MGNREGA}

\section{Awareness}

The issue of lack of awareness on MGNREGA emerges as one of the hindrances to the local villagers. According to the Act, sufficient awareness amongst the intended beneficiaries regarding provisions like guaranteed days of employment, unemployment allowance, minimum wages, availability of complaint register, etc. are necessary, however, the findings of the study area sheds light on the fact that the beneficiaries are not aware of the clauses of the Act across all the hamlets. For instance, when questioned about whether beneficiaries knew about the time span of getting employment from the date of the submission of applications under the MGNREGA, only 16 (20\%) respondents revealed that they were aware of that there is a guideline where it is mandatory for the beneficiaries to seek employment within the 15 days from the date of application for jobs.

The major source of information for the villagers regarding MGNREGA is PRIs including Anchal Samiti Member (ASM) representing whole village and Gram Panchayat Members (GPMs) representing certain segments of the village. Around $72.5 \%$ of the respondents claimed that they received information about MGNREGA from the Panchayat office which indicates that GP officials are playing a significant role in spreading information on this employment Act (Table 2).

Indeed, a large section of the respondents (that is, 59 or $73.8 \%$ ) across the Panchayats reported that they hardly see notifications in advance regarding the MGNREGA meetings. This perhaps, indicates that the Panchayats does not widely circulate notices. The place and mode of notification may also cause hindrance because the notifications are generally put in the government offices and villagers hardly visit these offices. They visit such offices only when they desperately feel to do so. Further, most of the job seekers being illiterate do not have the ability and inclination to read the notification even when it is written in the vernacular language. This is likely to restrict not only the job-seekers' participation in the scheme but also the incorporation of their needs and views in works.

\section{Mismanagement of Job-cards}

The majority of the households, that is, 54 (83.10\%) expressed that they received their job-cards without waiting for much time and without unnecessary visits to Gram Panchayat (GP) office while 11 households (16.90\%) claimed that they had to visit many times to Gram Panchayat (GP) office even Block Development Office (BDO) for seeking their job-cards. During the study, it was revealed that few villagers first got employment without the card and after working for some days, received their job-cards at the work-place. Research evidence unfolded that bribes (in the form cash and kind) were also taken by Government employees, affluent families, by the Anchal Samiti Members (ASM) and Gram Panchayat Members (GPMs) in order to give one or more job-cards to a single household. 
Table 2: Sources of Receiving Information on MGNREGA by the Respondents

\begin{tabular}{|l|c|c|}
\hline \multicolumn{1}{|c|}{ Sources of Information } & No. of Respondents & Percentage of Respondents \\
\hline Panchayat Office & 58 & 72.5 \\
\hline Media-Radio & 12 & 15 \\
\hline Neighbour & 6 & 7.5 \\
\hline Any Other & 2 & 2.5 \\
\hline NA & 2 & 2.5 \\
\hline
\end{tabular}

\section{Source: Survey Data}

Also, the research witnessed that there is religion and street biases and favouritism in obtaining job-cards. Some of the tribal women claimed that as the ASM belongs to a particular segment of the panchayat, he ignored their demand for the cards on many occasions. However, due to the interference of the BDO, few of them received the cards. As per the MGNREGA guideline, affixing of photographs on job-cards is mandatory but are free of cost. However, there were many job-cards found without photographs on them. There is also manipulation of job-cards by the Panchayat members for which in most of the job-cards, entries were either fake or blank. One possible solution to curb the mismanagement is to link the beneficiaries into technological infrastructure provided by a biometricallyauthenticated system like Aadhaar. ${ }^{1}$ This has the potential to reduce corrupt practices carrying out by panchayat leaders and officials, and also over reporting that takes place without the knowledge of the beneficiary or through ghost workers.

\section{Application for Employment}

The average number of respondents applied for employment is very low in the study village. Those who applied for the job are mostly conscious beneficiaries, and among them, not many people received unemployment allowance. Still, most of them feel that the job

\footnotetext{
${ }^{1}$ Aadhaar is a 12-digit unique identification number issued by the Indian Government to every individual resident of India as an attempt towards having a single, unique identification document or number that would capture all the details, including demographic and biometric information. As per the recent ruling of the Supreme Court of India on 26 September 2018, Aadhaar linking is mandatory for an individual to avail facilities of welfare schemes of the government like MGNREGA.
}

they used to get through MGNREGA is nothing but the mercy of ASM or GPMs. The research finding reveals that even in some cases, those who are needy of those cards have not received the cards, whereas few villagers who works in the public sectors have taken jobcards and are not at all applying for a job. Thus, among the job cardholders, 56 (86.15\%) of people have worked under MGNREGA while 9 (13.85\%) have failed to apply for a job.

Regarding the duration of MGNREGA employment, the respondents shared that they have not availed complete 100 days in a year. Even in the last five years, nobody obtained 100 days of employment. The villagers of Hiya Gram Panchayat worked under MGNREGA for around only 20-25 days in the last five years. Only about $10-15 \%$ of households received around 50 or more days of works in the last five years.

\section{Poor Quality of Works}

The improper execution of works is a matter of concern throughout this Panchayat as the approved works are not always publicly displayed. The tribal villagers revealed that they It was revealed by the tribal villagers that they were not aware of the Panchayat or Gram Sabha meetings regarding the activities of MGNREGA in the village. This replicates the non-participation of the villagers or community in the decision-making process of the village. The villagers used to work in any work assigned by the contractor or ASM. The internal understanding between contractors, ASM and Junior Engineer (JE) used to confine the work in paper only. Site account registers in respect of receipt and issue of materials to the work and temporary advance register in respect of advance availed for payment of wages had not 
been maintained, despite their mandated requirement for departmental execution under MGNREGA guidelines.

\section{Poor Planning and Lack of Coordination among Villagers and Officials}

The majority of the population said that only small works like constructing ponds had been undertaken in the village, although some other constructing works had been taken up and are incomplete due to conflicts among the villagers as well as between members of the Panchayat and Government officials.

\section{Payment of Wages}

The data from the field reflected that there is massive irregularity in payment of wages to the beneficiaries. While only 14 (21.54\%) of beneficiaries claimed that they received the wages within a month, the rest claimed that there is no certainty in receiving wages, usually for about two months or even more. The contractors or ASM were quite conscious while paying the wages by delaying in paying wages to those labourers who are illiterate and have no voice. It is observed from the field that 51 (78.46\%) beneficiaries do not have minimum wages fixed by the centre. While the MGNREGA guidelines permit equal wages for equal work, it fails to be a reality in the Hiya village.

Although MGNREGA has become organised nowadays through the transfer of wages to the accounts of the beneficiaries, in the study village, $43(66.15 \%)$ of the sample beneficiaries have not opened their account either in the bank or in the post office while 22 (33.85\%) of the sample beneficiaries have an account. It may be due to lack of interest or lack of awareness.

\section{Worksite Facilities}

A proper working condition is a prime obligation for ensuring safety of workers, particularly in the case of women, is much more critical. As per the MGNREGA guidelines, it is mandatory to have basic facilities such as safe drinking water, first-aid kits, shades, a period of rest, and also childcare (crèche) facilities at the worksite. However, it was observed that except for drinking water, no other facilities were arranged at the worksite (Fig. 2). Even some respondents claimed that in some cases drinking water was also carried by themselves from their respective home. While discussing the worksite facilities like availability of shade, some of the respondents claimed that the trees nearby worksite were used and treated as shady shelters. Thus, manipulation by the local implementing agencies and the absence of any monitoring mechanism at the same time resulted in the creation of unsafe and sub-standard working conditions in the village. These findings bear resonance to the findings as reported by Holmes, Sadana, and Rath (2010; 2011).

\section{No Social Audit Held}

The operational guideline detailed the procedure of Social Audit forums to be held by Gram Sabha on MGNREGA activities within every six months. However, in this village, Social Audit has never been held. Moreover, all the respondents of the research are unaware of the Social Audit. This evidence is also reflected in the study carried out by Sissal \& Sharma (2014). 


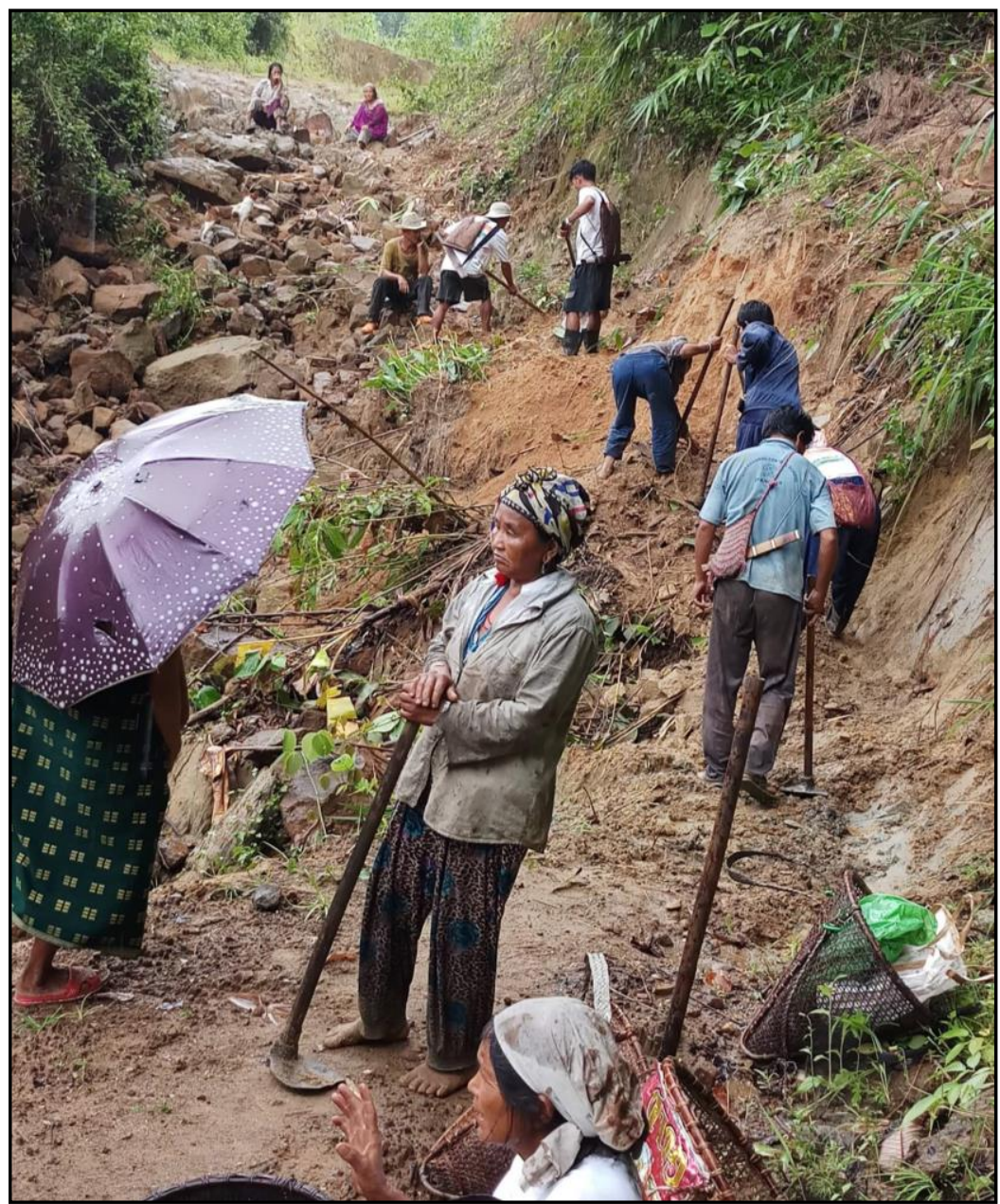

Figure 2: Workers Engaged in the Works Without Basic Facilities.

Source: Fieldwork

\section{Child Labour under MGNREGA}

According to MGNREGA guidelines, only adult members above 18 years who are interested in doing unskilled work at the statutory minimum wage can work under MGNREGA, but in Hiya village, small children are sometimes found- working at the sites. These children mostly working instead of their parents who engage themselves in some other domestic works during that time (Figure 3). Thus, it fails to prevent one of its targets, that is, child labour.

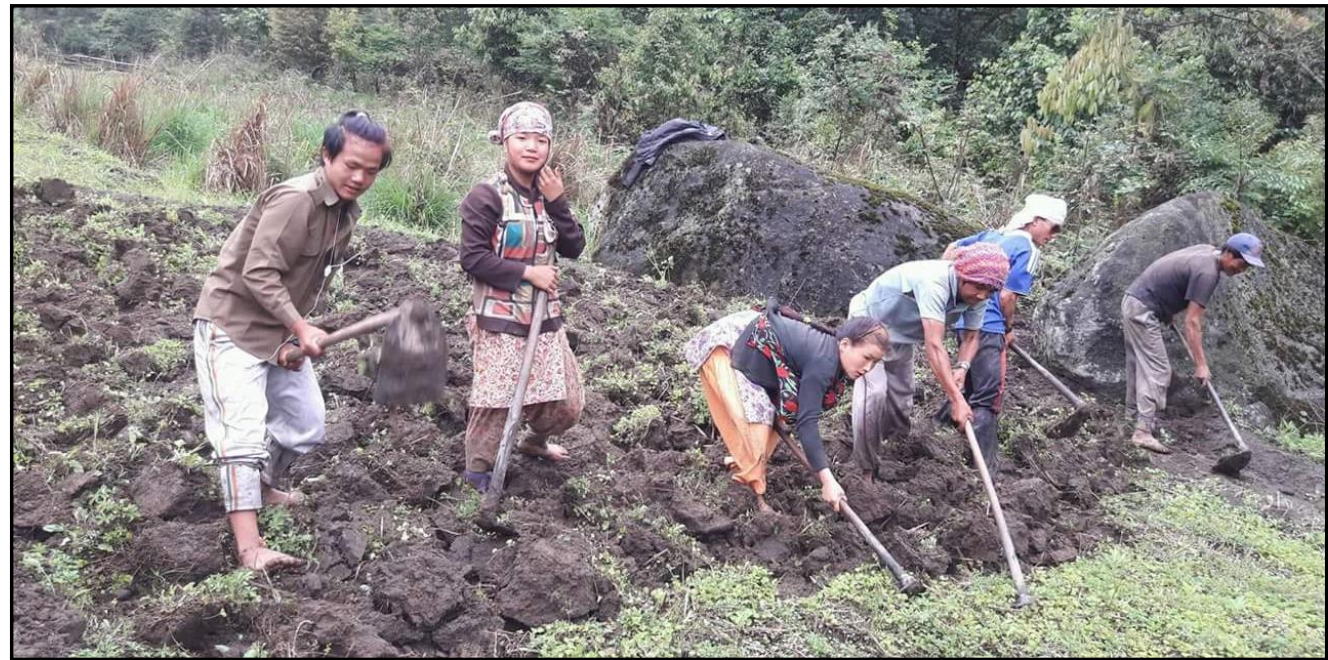

Figure 3: Children Below the Permitted Age Working Instead of their Parents Source: Fieldwork 


\section{Names of Dead Persons}

There is no proper verification while allotting the job card to the individuals. The research unveiled that in some cases, the ghosts (the already dead persons) have been receiving job and the job card. It also came to surface that in few incidents the children are using job card of their father who is already dead.

\section{Profile of Non-Job Cardholder Households}

As already stated above, out of 80 sample households for this study, 15 (18.75\%) households are the non-job cardholders. This may be due to their lack of interest to work under the MGNREGA as they have greater mobility for alternative money-making job opportunities even at a distance place.

Among the sample non-job cardholder households, 9 (60\%) households have already applied for job cards. The waiting time after the applications for job cards as reported by the respondents vary between 6 months to 2 years. The reasons for non-issuance of job cards are due to several factors such as relative sociopolitical and economic strength of the households in the village, awareness level, close relationship with the PRI functionaries, etc. This means the households having close relations with Panchayat leaders and Government officials have a high chance to obtaining job-cards and vice-versa. Those who have not applied for job-cards may be due to lack of interest and awareness because they have their reliable occupations.

\section{Role of Anchal Samiti Member (ASM) in MGNREGA}

The ASM is the most important agent of implementation of the MGNREGA as ASM works at the village level with the help of Gram Panchayat Members (GPMs). They are involved in the planning, designing and implementation of MGNREGA at their respective jurisdiction. Awareness of the ASM regarding different aspects of the scheme is thus crucial for its successful implementation. However, the findings revealed that the present ASM of the village is not much active and is aware of MGNREGA. The findings further suggest that some of the close relatives of ASM who are contractors mislead the entire programme. While distributing work and job-cards, ASM takes care of only those who voted for him.

\section{MGNREGA and Tribal Livelihoods}

It can be argued that MGNREGA is the most unique scheme to boost up the overall quality of life of rural households. As already mentioned, one of the key objectives of the scheme is to improve the income levels and enhance the livelihood security in rural areas with 100 days of wage employment guarantee in a financial year to every registered household. However, the fieldwork data reveals that MGNREGA has little impact on tribal livelihoods. By comparing the annual income of the beneficiaries before and after MGNREGA, it is found that there is an increase of $28.52 \%$ in income of the beneficiaries. Likewise, there is an increase of $47.42 \%$ in the expenditure of the beneficiaries. Before the implementation of MGNREGA, the villagers were generally spending $64.24 \%$ from their income while after the implementation of this scheme they are spending $73.69 \%$ of their income.

It is apparent from Table 3 that due to a change in income there is also a change in expenditure. Usually, the expenditure of the villagers was more on food items (69.13\%). However, after the implementation of this scheme, the expenditure on food items gradually shifted to non-food items which include both luxury and necessity items. For this, the expenditure on food items is gradually decreasing (59.29\%) and on non-food items is increasing. This reflects that there is some impact on tribal livelihoods, but this impact can be considered as meagre.

In all three hamlets including Hiya-I, Hiya-II and Lumtey, people had expressed their disappointments with MGNREGA works. Responses regarding MGNREGA may found in Figure 4 which shows that most of the respondents, that is, $55(68.75 \%)$ have the negative opinion on MGNREGA activities while $19(23.75 \%)$ are positive about the activities of MGNREGA; 6 (7.5\%) of them have no idea about the works under MGNREGA (Figure 4). 
Table 3: Source Wise Annual Households' Expenditure Before and after MGNREGA

\begin{tabular}{|l|c|c|}
\hline \multicolumn{1}{|c|}{ Source of Expenditure } & Before MGNREGA & After MGNREGA \\
\hline Food & $69.13 \%$ & $59.29 \%$ \\
\hline Clothing & $7.68 \%$ & $8.28 \%$ \\
\hline Health & $3.46 \%$ & $3.57 \%$ \\
\hline Cooking Fuel & $0.99 \%$ & $1.24 \%$ \\
\hline Education & $0.9 \%$ & $1.2 \%$ \\
\hline Transport & $2.14 \%$ & $2.63 \%$ \\
\hline Social/Religious Function & $3.95 \%$ & $4.55 \%$ \\
\hline Electricity Bill & $0.96 \%$ & $2.83 \%$ \\
\hline Agri. Equipment \& Seeds & $2.36 \%$ & $2.31 \%$ \\
\hline Household Assets & $1.38 \%$ & $2.04 \%$ \\
\hline Recreation & $0.27 \%$ & $0.31 \%$ \\
\hline Maintenance of House & $4.52 \%$ & $7.01 \%$ \\
\hline Source: Field Data & & \\
\hline
\end{tabular}

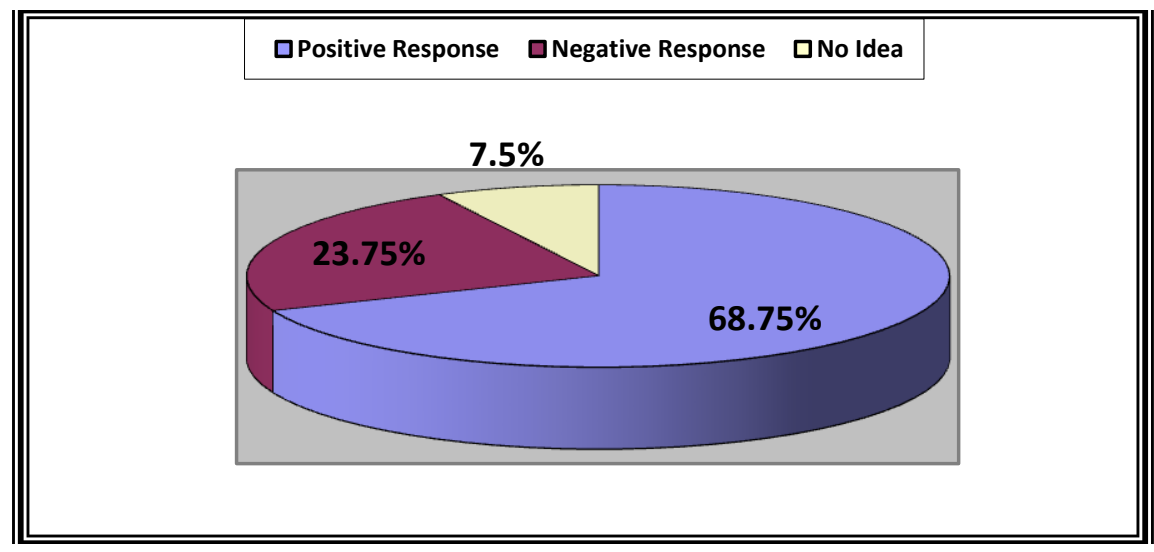

Figure 4: Responses about MGNREGA by Respondents Source: Field Data

\section{Impact on Migration}

By securing livelihood, MGNREGA aims at mitigating seasonal migration, and has been a significant source of employment and income for a large proportion of the rural population. However, there are two types of risks associated with working under MGNREGA. First, in most of the cases, the wages are paid on piece rate basis depending on the performance of the workers irrespective of their gender; a worker may get even less than the minimum prevailing market wage rate. Second, as per the provisions under the scheme, a household should get a minimum 100 days of employment. However, the Gram Panchayat fails to provide 100 days of employment to job seekers. Such limited and irregular supply of works restricts the job- seekers from working under MGNREGA. Regular employment opportunities also motivate many of the job-seekers to migrate to other places like Ziro, Naharlagun, Itanagar, etc.

\section{Conclusion}

MGNREGA is landmark social security legislation in India after independence. Rewarding the long-pending necessity for a comprehensive Employment Guarantee Act, this legislation is a partial victory towards a fullfledged right to employment. The present study critically examined the implementation process of MGNREGA and its impact on tribal livelihoods in a village located in one of the most backward districts of Arunachal Pradesh.

From the preceding discussions, one can conclude that the MGNREGA, which was 
introduced in giving justice to the common man, has failed in meeting the desired needs of the poor tribal villagers. It further reveals that though MGNREGA is well-intended legislation, a powerful tool in the hands of the common people to get their primary livelihood, its poor execution deprives them off their fundamental rights. While the target is to give 100 days of employment guarantee to each household, this village is yet to achieve this target because the approach in which MGNREGA should function is yet to be experienced in the village. Job-cards fail to reach the beneficiaries at a time bound manner and the unemployment allowances for the failure to employ within 15 days of the application according to MGNREGA guidelines were not followed. Though there is a little change in expenditure pattern of households, it fails to stop the flow of distress rural-urban migration, restricting child labour, alleviating poverty, and making village self-sustaining through productive assets creation as only few small works and other incomplete works were taking place in the village. Therefore, a concerted effort is required to tackle these problems of MGNREGA in this village.

There is nothing to deny that MGNREGA has turned to be a bonanza for the intermediaries rather than true beneficiaries. The implementation is indeed half-baked. There is a pressing need to get rid of the corruption in the delivery system of job and job-cards to the poor tribal villagers. Besides, a comprehensive mechanism is need of the hour in order to provide the MGNREGA wages directly to the workers or beneficiaries.

The success of MGNREGA in the village depends upon its proper implementation. Much of the drawbacks of MGNREGA can be surmounted, if proper processes and procedures are put in place. Hence, there should be constant efforts towards creating passable awareness on different provisions of this Act amongst the tribal villagers. Giving awareness is crucial not only to motivate the people to work but also to encourage them to participate in the planning and implementation of the programme.
Therefore, by summing up the preceding discussions on MGNREGA and its myriad aspects, following suggestions may be made to see this vital scheme more effective in and around the study area:

- Efficient utilisation of resources under the scheme requires bringing in transparency and accountability. Provision for social audit at the panchayat level on a regular basis can play a significant role in this regard.

- The leadership style should be democratic in nature. This will facilitate greater community participation, information sharing, expression of opinion by the rural mass, and development of social networks.

- The Government must take immediate steps to stop corruption in its implementation by which the MGNREGA wages reaches straight to the workers.

- A proper monitoring mechanism should be developed that can assure correct procedure in getting job-cards.

\section{References}

Bhattacharjee, G. (2017). MGNREGA as distribution of dole. Economic \& Political Weekly. LII (25 \& 26), 29-33.

Bit, J., and Banerjee, S. (2013). Livelihood dependence, traditional knowledge conservation, and sustainable forest management: A study on Birbhum forest division, West Bengal. Arthaniti, 12 (1 \& 2), 1-27.

Borah, K., and Bordoloi, R. (2014). MGNREGA and its impact on daily waged women workers: A case study of Sonitpur of Assam. IOSR Journal of Economics and Finance, 4(4), 40-44.

Chatterjee, S. (2017). Rural development schemes/yojanas focusing on first common review mission: A discussion. Journal for Studies in Management and Planning, 3 (6), 113-120. 
Das, D. (2012). Examining India's Mahatma Gandhi National Rural Employment Guarantee Act (MGNREGA): Its impact and women's participation.International Journal of Research in Management, 2(6), 209-218.

Didde, S.R., and Muthaiyan, P. (2013). Employment generation under MGNREGA in tribals Andhra Pradesh: Testimony of five years. IOSR Journal of Humanities and Social Science, 9(4), 55-64.

Gupta, T. (2014). MGNREGA and empowerment of disadvantaged groups. International Journal of Multidisciplinary Educational Research, 3(6,1), 229-245.

Holmes, R., Sadana, N., and Rath, S. (2010). Gendered risks, poverty and vulnerability in India: Case study of the Indian Mahatma Gandhi National Rural Employment Guarantee Act (Madhya Pradesh). London: Overseas Development Institute.

Holmes, R., Sadana, N., and Rath, S. (2011). An opportunity for change? Gender analysis of the Mahatma Gandhi NationalRural Employment Guarantee Act (Project BriefingNo. 53). London: Overseas Development Institute.

Koyu, B., Sarkar, A., Singh, R., \& Singh, R.J. (2017). Is MGNREGA myth for Arunachal Pradesh? Field evidence. Economic Affairs, 62(2), 313-319. DOI: 10.5958/09764666.2017.00014.6.

Menon, P. and Dixit, D. (2013). Starving India: Food security vis-à-vis right to food in Indian context. OIDA International Journal of Sustainable Development, 6 (9), 47-57.

Mishra, P., Behera, B., and Nayak, N. C. (2010). A development delivery institution for the tribal communities: Experience of the national rural employment guarantee scheme in India. Development Policy Review, 28 (4), 457-479.

Ramya, T. (2014). Socio-economic development of Arunachal Pradesh: A study-based reflection from Nyishi tribal village. In
Anupam Hazra (ed.),Sustaining development in North-Eastern India: Emerging issues, challenges, and policy measures (pp. 159-187). New Delhi: Concept Publishing Company Pvt. Ltd.

Rengasamy, K., and Kumar, B. S. (2011). State level performance of MGNREGA in India: A comparative study. International Multidisciplinary Research Journal, 1(10), 36-40.

Sissal, T., Sharma, A. (2014). A study on knowledge and perceptions of beneficiaries towards MGNREGA in Doimukh panchayat of Papum Pare district.International Journal of Advance Research in Computer Science and Management Studies, 2(10), 13-18.

\section{About the Author}

Tame Ramya, M.A., MPhil, UGC-NET/JRF, is an Assistant Professor of Anthropology under Faculty of Social Sciences at Dera Natung Government College, Itanagar. His area of specialisation is social \& cultural anthropology. Ramya is currently engaged in doctoral research at the Department of Anthropology, Rajiv Gandhi University, Arunachal Pradesh. He has co-authored/co-edited two books, Contesting Voices, Changing Realities: The Nyishis of Arunachal Pradesh (2017) and Tribals in the Contemporary Context: Myriad Perspectives from Northeast India (2018). Ramya has many research paper publications and presentations in the national and the international fora. His research interests include tribal and rural development interventions, religious studies, tribal ethnography, anthropological linguistics, tribal resource management, women \& gender studies, and tribal cultural tourism. He is a life member of the Indian Anthropological Society (IAS), the Indian National Confederation and the Academy of Anthropologists (INCAA), the Indian Science Congress Association (ISCA), the Global Association for Humanities and Social Science Research (GAHSSR), and the Arunachal Anthropological Forum (AAF). 